\title{
ANALYSIS OF THE EFFECTIVENESS OF THE PHARMACY NETWORK
}

\author{
DOMINIK GREGA $^{1} *$, TÜNDE AMBRUS ${ }^{1}$, ADAM MATEJOVIČ ${ }^{2}$, MARTINA ŠUTOROVÁ $^{1,3}$, \\ JOZEF KOLÁR̆ ${ }^{4}$ \\ ${ }^{I}$ Department of Applied Pharmacy, Faculty of Pharmacy, Masaryk University; Palackého tř. 1946/1, 61242 Brno, the Czech \\ Republic \\ ${ }^{2}$ Department of Virology, Tohoku University Graduate School of Medicine, Seiryo-machi 2-1, Aoba-ku, Sendai, Miyagi, 980- \\ 8575, Japan \\ ${ }^{3}$ Department of Pharmacy and Social Pharmacy, University of Veterinary Medicine and Pharmacy in Košice; Komenského \\ 73, 04181 Košice, the Slovak Republic \\ ${ }^{4}$ Department of Social and Clinical Pharmacy, Faculty of Pharmacy, Charles University, Akademika Heyrovského 1203, 500 \\ 05 Hradec Králové, the Czech Republic
}

*corresponding author: grega.dominik@gmail.com

Manuscript received: January 2021

\begin{abstract}
The legal framework for pharmacy has been frequently changed after the foundation of present-day Slovakia in 1993. The establishment of new pharmacies was regulated and based on geographical criteria in the past. This article aimed to evaluate the impact of geographical restrictions removal on the number of newly established pharmacies in Slovakia and assessed their financial performance in the period from 1998 to 2017. Selected financial indicators, demographics, and the number of inhabitants per community pharmacy have been assessed. $25 \%$ of community pharmacies in Slovakia showed a negative return on sales (ROS), total debt higher than the average of Slovak healthcare, and did not maintain the expected range of current liquidity status. Overall, $16 \%$ and $31 \%$ of pharmacies were unprofitable based on the Altman Z score and Index 05 , respectively. While the number of inhabitants remained relatively unchanged, the number of community pharmacies doubled during the observed period. Based on the results, we designed models to decrease the number of pharmacies and increase the inhabitant/pharmacy ratio to improve pharmacies' financial performance. We propose to introduce regulating demographic criteria to establish new pharmacies based on our models. By regulating or reducing the number of pharmacies, it can be expected an increase in the offered pharmacy services. To maintain the quality and accessibility of pharmaceutical services in rural areas, providing financial support for community pharmacies could be an alternative.
\end{abstract}

\section{Rezumat}

Cadrul legal pentru farmacii a fost modificat frecvent după înființarea Slovaciei actuale în anul 1993. În trecut, înființarea de noi farmacii era reglementată și bazată pe criterii geografice. Acest articol urmărește evaluarea impactului eliminării restricțiilor geografice asupra numărului de farmacii nou înființate în Slovacia, precum și evaluarea performanței financiare a acestora în perioada 1998 - 2017. Au fost evaluați indicatori financiari, date demografice şi numărul de locuitori pentru o farmacie comunitară. $25 \%$ dintre farmaciile comunitare din Slovacia au prezentat o rentabilitate negativă a vânzărilor (ROS), datorii totale mai mari decât media asistenței medicale slovace și nu au menținut intervalul preconizat al lichidităților. În general, $16 \%$ şi $31 \%$ din farmacii au fost nerentabile pe baza scorului Altman Z şi, respectiv, a Indicelui 05. În timp ce numărul de locuitori a rămas relativ neschimbat, numărul farmaciilor comunitare s-a dublat în perioada analizată. Pe baza rezultatelor, am conceput modele pentru a reduce numărul de farmacii și pentru a crește raportul locuitor/farmacie în scopul îmbunătățirii performanței financiare a farmaciilor. În concluzie pe baza modelelor noastre propunem să introducem criterii demografice pentru reglementarea înființării de noi farmacii ceea ce va îmbunătății serviciile oferite. Pentru a menține calitatea și accesibilitatea serviciilor farmaceutice în zonele rurale, furnizarea de sprijin financiar pentru farmaciile comunitare ar putea fi o alternativă.

Keywords: pharmacies, demographic regulation, ownership, financial analysis

\section{Introduction}

Since its inception, the field of pharmacy has undergone individual developmental stages and significant changes. Similarly, the pharmacy has changed since the differentiation of the pharmaceutical branches. Changes have taken place throughout the world, but individual differences are country-specific [4].
Since the foundation of the independent Slovak Republic in 1993, Slovak pharmacy has undergone several essential reforms reflected in numerous amendments to the Act on Medicines [1,2]. One of the most significant changes was the pharmacy's liberalization in 2004, which opened pharmacy ownership to non-pharmacists. The absence of legislation 
restrictions such as geographical, demographic, or ownership criteria to establish new pharmacies increased the number of pharmacies. In recent years, pharmacies have become concentrated in densely populated urban areas compared to sparsely populated rural areas. On average, Slovak citizens have access to a community pharmacy within 25 minutes from the place of residence [30].

After the foundation of present-day Slovakia in 1993, the formation of the pharmacy network was initially supposed to be based on demographic and geographical criteria, like, for example, the minimum distance between pharmacies of 150, 300 and 500 meters. Nevertheless, these criteria were later abolished by the Ministry of Health. Pharmaceutical care is part of the healthcare system and services [3]. Furthermore, pharmacies also act as retail stores in terms of economic activity [21]. In the environment driven by the general law of supply and demand, pharmacies act as healthcare providers and commercial entities at the same time. Therefore, community pharmacies must generate profit to cover operating costs and to avoid a net loss. This study's objective was to assess the pharmacy network's efficiency in Slovakia based on financial performance and demographics. This article aims to propose a reduction in the number of community

pharmacies while maintaining a high quality of pharmaceutical care as its utmost importance.

\section{Materials and Methods}

The input data for financial analysis of pharmacies for the year 2017 were obtained from FinStat portal (including aggregated bankruptcy indexes) [10]. The financial analysis evaluated ratios: return on sales (ROS), current liquidity, the total debt of pharmacies, and aggregated bankruptcy indexes Altman Z score and Index 05. Aggregated bankruptcy indexes are formulas used to predict the probability of bankruptcy and are essential indicators assessed in financial performance analysis. Several different business ratios with weighed coefficients are used for the calculations [31].

Demographic data were obtained from the database of the Statistical Office of the Slovak Republic (SOSR) [29]. The analysis monitored data on the median number of the permanently resident population in Slovakia and the number of pharmacies. From this data, the number of inhabitants per pharmacy was calculated. Demographic data were monitored at fiveyear intervals from 1998 to 2017. In the monitored period, the dynamics of development in individual quantities were calculated compared to the previous year.

Table I

Calculation method for the models to reduce the number of pharmacies

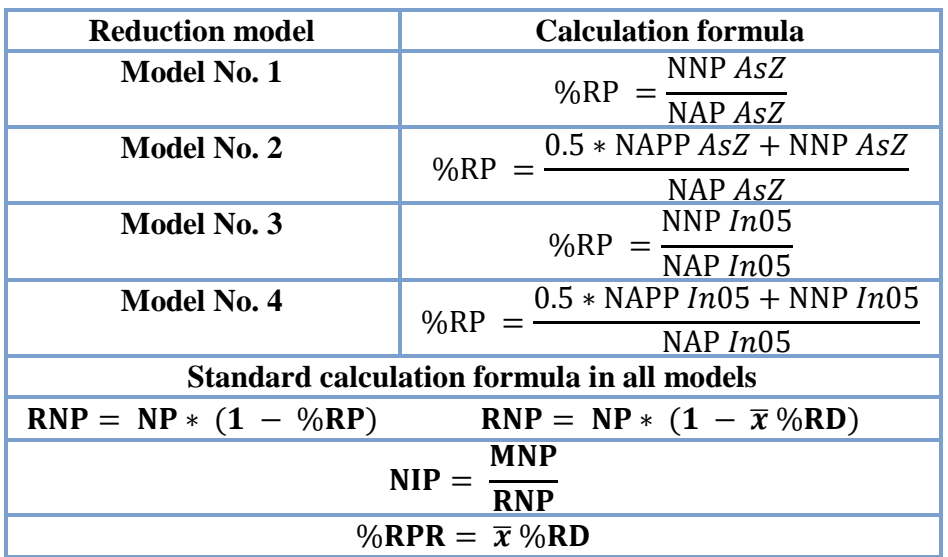

$\% \mathrm{RP}$ - percentage reduction of pharmacies in the district; NNP - number of unprofitable pharmacies in the district; NAP - number of all pharmacies in the district; NAPP - number of average profitable pharmacies in the district; AsZ - Altman Z score values; In05 - Index 05 values; RNP - number of pharmacies in the district/region after reduction; NP - number of pharmacies in the district/region based on SOSR; $\mathrm{NIP}$ - number of inhabitants per pharmacy in the district/region; MNP - median number of permanent population in district/region;

$\% \mathrm{RPR}$ - percentage reduction of pharmacies in the region; $\overline{\boldsymbol{x}} \% \mathrm{RD}$ - arithmetic mean of percentage reduction in districts from a particular region

To calculate the reduction in the number of pharmacies, four models were constructed based on Slovakia's financial performance and demographics. The critical input indicators used in the models were the number of pharmacies, population, and aggregated bankruptcy indexes. The percentages of unprofitable and profiting on average pharmacies were calculated from these indexes. Calculations to reduce the number of pharmacies were based on four models with specific criteria (Table I).

\section{Results and Discussion}

There are eight regions in Slovakia. Out of 1,724 pharmacies in total, we collected data from 1,698 (98.5\%) pharmacies to evaluate their financial performance in 2017. The Altman Z score values were collected from 1,496 pharmacies in Slovakia $(86.8 \%)$ the Index 05 values were collected from 1,490 pharmacies (86.4\%). Compared to the average debt in Slovak health care, $25 \%$ of community pharmacies reported negative return 
FARMACIA, 2021, Vol. 69, 4

on sales (ROS) and did not maintain the expected range of current liquidity status. $16 \%$ of pharmacies were unprofitable based on the Altman Z score, while

based on Index 05, 31\% did not generate any profit. The results of the financial analysis are shown in Table II.

Table II

Financial analysis of community pharmacies in 2017

\begin{tabular}{|c|c|c|c|c|c|c|}
\hline Ratios & Minimum & Maximum & Average & Median & 25. percentile & 75. percentile \\
\hline ROS & -71.329 & 28.282 & -0.084 & 0.012 & -0.007 & 0.026 \\
\hline ROS gross & -64.471 & 25.906 & -0.062 & 0.017 & -0.003 & 0.032 \\
\hline Current liquidity & $-17,645.000$ & 310.036 & -8.157 & 1.104 & 0.805 & 1.736 \\
\hline Total debt & -9.544 & $120,170.000$ & 74.142 & 0.840 & 0.567 & 0.968 \\
\hline \multicolumn{7}{|c|}{ Results of the financial analysis divided by category* } \\
\hline Aggregated bankruptcy indexes & $\begin{array}{c}\text { Profitable } \\
(>\mathbf{2 . 6} />\mathbf{1 . 6})\end{array}$ & $\mathbf{\%}$ & $\begin{array}{c}\text { Unprofitable } \\
(<\mathbf{1 . 1} /<\mathbf{0 . 9})\end{array}$ & $\mathbf{\%}$ & $\begin{array}{c}\text { Averagely profitable } \\
(\mathbf{1 . 1}-\mathbf{2 . 6 / 0 . 9}-\mathbf{1 . 6})\end{array}$ & \% \\
\hline Altman Z score & 913 & 61.03 & 246 & 16.44 & 337 & 22.53 \\
\hline Index 05 & 578 & 38.79 & 463 & 31.07 & 449 & 30.13 \\
\hline
\end{tabular}

*Pharmacies were divided into categories according to the aggregated bankruptcy indexes.

Altman $\mathrm{Z}$ score and Index 05 values are indicated in parenthesis, respectively.

Table III

Demographics of Slovakia in 1998 - 2017

\begin{tabular}{|l|c|c|c|}
\hline & Median number of permanent residents & Number of pharmacies & Number of inhabitants per pharmacy \\
\hline $\mathbf{1 9 9 8}$ & $5,390,657(100.00 \%)$ & $952(100.00 \%)$ & $5,662(100.00 \%)$ \\
\hline $\mathbf{2 0 0 3}$ & $5,378,821(-0.22 \%)$ & $1,065(+11.87 \%)$ & $5,051(-10.81 \%)$ \\
\hline $\mathbf{2 0 0 8}$ & $5,404,784(+0.48 \%)$ & $1,306(+22.63 \%)$ & $4,138(-18.06 \%)$ \\
\hline $\mathbf{2 0 1 3}$ & $5,412,008(+0.13 \%)$ & $1,487(+13.86 \%)$ & $3,640(-12.05 \%)$ \\
\hline $\mathbf{2 0 1 7}$ & $5,437,754(+0.48 \%)$ & $1,724(+15.94 \%)$ & $3,154(-13.34 \%)$ \\
\hline
\end{tabular}

Data in brackets show a percentage increase/decrease compared to the previous reporting period.

The demographic analysis revealed that the number of inhabitants remained relatively unchanged, and conversely, the number of community pharmacies doubled during the observed period. The results of the demographic analysis are presented in Table III.

The percentage increase in the number of inhabitants per pharmacy based on model No. 1 and 2 is similar to the proposed percentage reduction of pharmacies. The percentage increase in the number of inhabitants

per pharmacy based on model No. 3 and 4 are 1.5 - 2 times more than the proposed percentage reduction. According to the financial performance, the higher ratio in models 3 and 4 is caused by a stricter categorisation of community pharmacies. Inhabitants per pharmacy ratios after applying the percentage reduction of pharmacies and the values of percentage reduction of pharmacies in individual regions according to models No. 1 - 4 are shown in Table IV.

Table IV

Percentage reduction of pharmacies and population increase per pharmacy by region after reducing the number of pharmacies based on models No. 1 - 4

\begin{tabular}{|l|c|c|c|c|c|c|c|c|}
\hline \multirow{1}{*}{ Region } & Model & No. 1 & Model & No. 2 & Model & No. 3 & Model & No. 4 \\
\cline { 2 - 9 } & \%RPR & NIPaR & \%RPR & NIPaR & \%RPR & NIPaR & \%RPR & NIPaR \\
\hline Bratislava & 12 & $2,921(+13 \%)$ & 26 & $3,465(+35 \%)$ & 31 & $3,745(+45 \%)$ & 47 & $4,834(+88 \%)$ \\
\hline Trnava & 8 & $3,279(+9 \%)$ & 17 & $3,621(+21 \%)$ & 28 & $4,174(+39 \%)$ & 45 & $5,469(+82 \%)$ \\
\hline Trenčín & 5 & $3,283(+6 \%)$ & 17 & $3,734(+20 \%)$ & 31 & $5,619(+81 \%)$ & 45 & $5,619(+81 \%)$ \\
\hline Nitra & 15 & $3,701(+18 \%)$ & 24 & $4,146(+32 \%)$ & 28 & $4,360(+39 \%)$ & 46 & $5,787(+85 \%)$ \\
\hline Žilina & 12 & $3,753(+13 \%)$ & 16 & $3,948(+19 \%)$ & 21 & $4,200(+26 \%)$ & 31 & $4,816(+45 \%)$ \\
\hline Banská Bystrica & 12 & $3,708(+13 \%)$ & 20 & $4,082(+25 \%)$ & 29 & $4,575(+40 \%)$ & 42 & $5,672(+74 \%)$ \\
\hline Prešov & 16 & $3,998(+19 \%)$ & 24 & $4,461(+32 \%)$ & 31 & $4,912(+46 \%)$ & 42 & $5,819(+73 \%)$ \\
\hline Košice & 8 & $3,794(+9 \%)$ & 22 & $4,480(+28 \%)$ & 30 & $4,946(+42 \%)$ & 43 & $6,097(+75 \%)$ \\
\hline Average & $\mathbf{1 1}$ & $\mathbf{3 , 1 5 9 ( + 1 3 \% )}$ & $\mathbf{2 1}$ & $\mathbf{3 , 9 9 2 ( + 2 6 \% )}$ & $\mathbf{2 9}$ & $\mathbf{4 , 5 6 7 ( + 4 5 \% )}$ & $\mathbf{4 3}$ & $\mathbf{5 , 5 1 4}(+\mathbf{7 5 \%})$ \\
\hline
\end{tabular}

$\%$ RPR - percentage reduction of pharmacies in the region; NIPaR - number of inhabitants per pharmacy in the region after reduction of pharmacies

Each bracket value shows the percentage increase in the number of inhabitants per pharmacy compared to the original number from 2017.

The financial indicators analysis revealed that pharmacies experience unstable financial situations $-25 \%$ of pharmacies were in a poor financial situation or on the verge of bankruptcy, and $25 \%$ of pharmacies had a negative ROS ratio. "The importance of ROS indicators is that their level and evolution reflect the level and evolution of liquidity, activity and indebtedness. It can, therefore, be argued that ROS indicators synthesize them" [14]. The recommended current liquidity (liquidity of $3^{\text {rd }}$ grade) ranges from 1.5 to 2.5 [27]. The current 
FARMACIA, 2021, Vol. 69, 4

liquidity status in Slovakia was not observed in more than $25 \%$ of pharmacies. The average value of total debt in health care is $67.6 \%$ [11]. $25 \%$ of evaluated pharmacies highly exceeded this value and were overindebted. According to the analysis of Mandžák and Hronček from 2017, more than $20 \%$ of pharmacies made no profit or were at a loss [24]. Compared to the analysis from the period 2007 - 2012 by Malovecká et $a l$., we conclude that there was a decrease in ROS based on our selected financial indicators. Current liquidity and total debt remained without any significant change [23]. The results of this comparison indicate a decline in the financial performance of community pharmacies.

We presume that the financial performance of some pharmacies could be on a decline due to increased competition. Compared to 2013, the number of community pharmacies increased by $15.94 \%$ in 2017 , while the population increased only by $0.48 \%$. The entry of the second pharmacy into the market in the area as a new competitor brings the benefits of the competitive market such as lower prices, more choice, or better quality of pharmaceutical care. However, a further increase in the number of pharmacies does not increase this effect and may cause a surplus of community pharmacies within the same area [21]. The liberalization of the pharmacy market has led to an increase in pharmaceutical care [28].

Additionally, it also caused inequities in community pharmacies' geographical distribution between cities and rural areas [21]. Up to $29 \%$ of the inhabitants in about 2,300 municipalities have no direct access to the pharmacy network [24]. The presence of a general practitioner in the municipality often contributes to establishing a rural pharmacy [21]. The number of inhabitants living in rural areas is five times lower than the OECD average, making it challenging to create new pharmacies in such municipalities. The density of pharmacies in Slovakia is above the world average of 4,200 inhabitants per pharmacy globally. The median of high-income countries is from 2 to 8 thousand inhabitants per pharmacy, while Slovakia ranks below the lower limit [24]. The Central European Health Policy Institute (HPI) reported an increase in the number of pharmacies by more than two-thirds confirming good accessibility of pharmaceutical care in Slovakia in its report evaluating the period from 2004 to 2014. It was also registered a $50 \%$ reduction in the number of inhabitants per pharmacy. Our data confirm a gradual increase in the number of pharmacies and a decrease in the number of inhabitants per pharmacy [30]. Malovecká et al. also confirmed an increase in the number of new pharmacies. The number of inhabitants per pharmacy decreased, which lead to higher market competition [22].

Based on the information about the financial situation of pharmacies and demographic development in Slovakia, we proposed four models to reduce market competition. Reduction in the number of pharmacies could improve pharmaceutical care and financial performance in pharmacies and may lead to new pharmacy services. Table IV shows a procedure for reducing the number of pharmacies. We found that approximately $25 \%$ of pharmacies demonstrated poor financial performance. Models No. 2 and 3 showed, on average, a 25\% reduction in the number of pharmacies and could be therefore applied in the modelling for pharmacy number reduction. At the same time, the ratio of inhabitants per pharmacy would increase by $26-45 \%$. The resulting values are comparable with the number of inhabitants per pharmacy ratio around the year 2008 (Table III). To implement geographical criteria in rural areas, the elderly might be at risk of decreased accessibility to pharmaceutical care as described in some regions of Portugal [26]. Thus, any possible regulation should be carefully planned.

The ECORYS study examined the impact of regulation and deregulation on the pharmacy market. Comparing the advantages and disadvantages of de-/regulation, in conclusion, it emphasized the benefits of deregulation. According to the study, pharmacists required financial compensations after deregulation. The study further discussed the freedom of establishment within the European Union concerning restrictions [36]. According to the Treaty on the Functioning of the European Union Art. 53, paragraph 2, the progressive abolition of restrictions in pharmaceutical professions shall depend upon coordination of the conditions for their exercise in the various Member States [7]. The Court of Justice of the European Union also issued its decision regarding the freedom of establishment and demographic, geographic and ownership restrictions. The Court ruled that the pharmacy's regulatory measures can be beneficial and are at the discretion of each member state. Based on the Court's judgment, regulations are applicable under these conditions applied in a non-discriminatory manner, follow the obligation in the public interest, suitable for securing the attainment of the objective which they pursue, and do not go beyond what is necessary for attaining that objective [16-19].

An example of well-known countries introducing geographical criteria for opening a new community pharmacy in their regulations is represented by Hungary or Austria. The regulations are based on the number of inhabitants per pharmacy, the distance between pharmacies, and ownership limited to pharmacists [15, 32, 33]. Estonia has postponed the introduction of some regulatory measures. The future effect of these changes is questionable, and the impact on pharmaceutical care is unclear [13]. An overview of valid demographic and geographical regulations for the foundation of new pharmacies in Europe from 2018 is given in Table V. 
Table V

Overview of the standard geographical and demographic criteria for opening new pharmacies in 2018 in Europe

\begin{tabular}{|c|c|c|}
\hline Country & $\begin{array}{c}\text { Demographic criteria } \\
\text { (Minimum number of inhabitants per pharmacy) }\end{array}$ & $\begin{array}{c}\text { Geographical criteria } \\
\text { (Minimum distance between pharmacies) }\end{array}$ \\
\hline Austria & 5,500 & $500 \mathrm{~m}$ \\
\hline Belgium & $\begin{array}{l}3,000 \text { for cities over } 30,000 \text { inhabitants } \\
2,500 \text { for cities between } 7,500-30,000 \text { inhabitants } \\
2,000 \text { for cities with less than } 7,500 \text { inhabitants }\end{array}$ & $\begin{array}{c}1 \mathrm{~km}, 3 \mathrm{~km} \text { or } 5 \mathrm{~km} \text {, depending on the } \\
\text { population }\end{array}$ \\
\hline Croatia & 3,000 & $200-500 \mathrm{~m}$ depending on the population \\
\hline France & $\begin{array}{l}\text { 2,500 for the first pharmacy, } \\
4,500 \text { for each additional pharmacy (rules are } \\
\text { adjusted in some regions) }\end{array}$ & - \\
\hline Hungary & $\begin{array}{l}4,000 \text { for cities over } 50,000 \text { inhabitants } \\
4,500 \text { for smaller towns }\end{array}$ & $250-300 \mathrm{~m}$ depending on the population \\
\hline Italy & 3,300 & $200 \mathrm{~m}$ \\
\hline Latvia & 2,000 & $500 \mathrm{~m}$ \\
\hline Malta & 2,500 & $300 \mathrm{~m}$ \\
\hline Poland & $\begin{array}{l}3,000 \text {, criterion not applicable if the pharmacy is } 1 \\
\mathrm{~km} \text { away from any other pharmacy }\end{array}$ & $500 \mathrm{~m}$ or $1 \mathrm{~km}$ \\
\hline Portugal & 3,500 & $250 \mathrm{~m}$ \\
\hline Republic of Moldova & Only for new pharmacies in cities: $3,000-4,000$ & $\begin{array}{l}\quad 250 \mathrm{~m} \text { from other pharmacies; } \\
\text { at least } 500 \mathrm{~m} \text { from individual pharmacies }\end{array}$ \\
\hline Romania & $\begin{array}{l}3,000 \text { in Bucharest } \\
3,500 \text { in county capital } \\
4,000 \text { in other cities } \\
\text { without criteria in rural areas }\end{array}$ & - \\
\hline Slovenia & 6,000 & $400 \mathrm{~m}$ in urban areas, $5 \mathrm{~km}$ in other areas \\
\hline Spain & 2,800 (criteria may be adjusted in regions) & $250 \mathrm{~m}$ (criteria may be adjusted in regions) \\
\hline Turkey & $\begin{array}{l}3,500 \text { (criterion not applicable if there is no pharmacy } \\
\text { in the area, they will be applied again when the } \\
\text { pharmacy is relocated) }\end{array}$ & \\
\hline
\end{tabular}

Access to healthcare is a fundamental human right and one of the fundamental principles of the European Union. It created a European Patient Forum (EPF), which outlines healthcare accessibility to patients. According to the EPF, healthcare should be: available including specialized services and all services leading to quality healthcare; adequate - taking into account the patient's actual needs; accessible - geographical circumstances should not be an obstacle, and care should be available in a reasonable time; appropriate relevant to the needs of different population groups, without discrimination; affordable - not only in terms of price as such but also psychosocial. National healthcare systems must finance adequate healthcare at affordable and fair costs [9].

The absence of geographical criteria can cause unequal access to community pharmacies in rural areas. Similarly, this is also reflected in the price differences between rural and urban pharmacies [20].

There are differences in opinions on the scale of demographic, geographical and ownership regulations. Reintroducing regulations is often defended by improving the quality of the provided pharmaceutical care in some countries. The paradox of liberalization in the pharmacy sector from a few years ago, which abolished geographical and demographic regulations, promised higher accessibility of pharmaceutical care and fewer
OTC medicines for the rural population. However, the deregulation did not meet any of these objectives [30]. Comparing the regulated and unregulated market, there was no difference in the quality of pharmaceutical care. Also, liberalization led to vertical and horizontal integration best observed in Norway and in the Netherlands, where large wholesalers owned $81 \%$ and up to $100 \%$ of pharmacies, respectively $[34,35]$. Geographical regulations are also supported by the analysis carried out in Pamplona, Spain, where different regulatory practices were compared with Sabadell's city [5]. The study of the effects of liberalization in Croatia [25] also supports the need for partial adaptation in the pharmaceutical segment.

Another solution is pharmacies' financial support in certain countries such as the Czech Republic, Sweden, Finland, Estonia, Spain, or Scotland. Bonification is granted to pharmacies in low financial standing and provide pharmaceutical care in remote areas where there is an interest in maintaining the healthcare available $[6,12]$.

\section{Conclusions}

The liberalization of the pharmacy sector in Slovakia led to an increase in the number of pharmacies. The findings in this study indicate a steady increase in 
the number of pharmacies disproportionate to the population. It would be helpful to implement demographic criteria or to reduce the current number of pharmacies. The models based on financial indicators used in this study (model No. 2 a 3 ) could reduce the number of pharmacies. Additional studies to further explore the implementation of regulation in pharmacy in Slovakia are required. We propose that further research should be undertaken in the following areas: the ratio of pharmacists per pharmacy concerning provided services, required/available pharmacists per pharmacy ratio, or the demand for additional pharmacist services, which can be implemented in community pharmacies in the future.

\section{Conflict of interest}

The authors declare no conflict of interest.

\section{References}

1. Act No. 140/1998 Coll. on Medicines and Medical Devices, on amending Act No. 455/1991 Coll. on craft enterprise (craft Act) amended by later regulations and about amending and supplementing of the Act of the National Council of the Slovak Republic No. 220/1996 Coll. About advertising, (available in Slovak).

2. Act No. 362/2011 Coll. on Medicines and Medical Devices and on amending certain laws, (available in Slovak).

3. Act No. 576/2004 Coll. on healthcare, services connected with the provision of healthcare and amending certain acts, as amended, (available in Slovak).

4. Anderson S, Making Medicines: A Brief History of Pharmacy and Pharmaceuticals. Pharmaceutical Press, London, 2005; 318.

5. Barbarisi I, Bruno G, Diglio A, Elizalde J, Piccolo C, A spatial analysis to evaluate the impact of deregulation policies in the pharmacy sector: Evidence from the case of Navarre. Health Policy, 2019; 123(11): 1108-1115.

6. Besançon L, Humbert T, Pedersen HB, The legal and regulatory framework for community pharmacies in the WHO European Region. WHO Regional Office for Europe, Copenhagen, 2019; https://apps.who.int/iris/ bitstream/handle/10665/326394/9789289054249-eng. pdf? sequence $=1 \&$ isAllowed $=y$.

7. Consolidated version of the Treaty on the Functioning of the European Union, Official Journal of the European Union, C 202/4, www.ecb.europa.eu/ecb/ legal/pdf/oj_c_2016_202_full_en_txt.pdf.

8. Czech Chamber of Pharmacists: There are no rules for the network of pharmacies in the Czech Republic, https://lekarnici.cz/getattachment/2adb7d85-d82d4c5b-902f-6e461da09e8f/CLnK-Pravidla-pro-sitlekaren.pdf.aspx., (available in Czech).

9. European Patients Forum (EPF): Defining and Measuring Access to Healthcare: the Patients' Perspective, Position Statement, 2016; www.eu-patient.eu/globalassets/ policy/access/epf_position_defining_and_measurin g_access_010316.pdf.

10. Finstat ${ }^{\circledR}:$ Companies with financial data - database of economic results of Slovak companies. https://finstat.sk/ databaza-financnych-udajov., (available in Slovak).
11. Finstat ${ }^{\circledR}:$ Financial analysis of companies in the Slovak Republic. https://finstat.sk/analyzy/financneukazovatele-slovenskych-firiem., (available in Slovak).

12. General Health Insurance Company of the Czech Republic. News. Bonification of pharmaceutical providers in unavailable areas in 2020; www.vzp.cz/o-nas/ aktuality/bonifikace-poskytovatelu-lekarenske-pece-vnedostupnych-oblastech-v-roce-2020., (available in Czech).

13. Gross M, Volmer D, Restrictions to Pharmacy Ownership and Vertical Integration in Estonia Perception of Different Stakeholders. Pharmacy (Basel), 2016; 4(2): 18: 1-9.

14. Gundová P, Rybovičová I, Development of selected financial indicators of the companies in the tourism sector. Mladá veda, 2016; 4: 172-185.

15. Hoffman P, Pharmacies: Crucial Differences In The DACH-Region. 2019, www.tec4med.com/pharmaciescrucial-differences-in-the-dach-region/.

16. Judgment of the Court (Fourth Chamber), 13 February 2014. Susanne Sokoll-Seebacher. Request for a preliminary ruling from the Unabhängiger Verwaltungssenat des Landes Oberösterreich. Freedom of establishment Public health - Article 49 TFEU - Pharmacies Adequate supply of medicinal products to the public Operating authorisation - Territorial distribution of pharmacies - Establishment of limits essentially based on a demographic criterion - Minimum distance between pharmacies Case C 367/12, http://curia.europa.eu/juris/ document/document.jsf?text=\&docid=147844\&pag eInde $=0 \&$ doclang $=$ sk \& mode $=1$ st $\&$ dir $=\&$ occ $=$ first \&part $=1 \&$ cid $=1860605$.

17. Judgment of the Court (Grand Chamber) of 1 June 2010. José Manuel Blanco Pérez and María del Pilar Chao Gómez v Consejería de Salud y Servicios Sanitarios (C-570/07) and Principado de Asturias (C-571/07). References for a preliminary ruling: Tribunal Superior de Justicia de Asturias - Spain. Article 49 TFEU Directive 2005/36/EC - Freedom of establishment Public health - Pharmacies - Proximity - Provision of medicinal products to the public - Operating licence Territorial distribution of pharmacies - Establishment of limits based on population density - Minimum distance between pharmacies - Candidates who have pursued professional activities on part of the national territory - Priority - Discrimination. Joined cases C570/07 and C-571/07, http://curia.europa.eu/juris/ document $/$ document.jsf?text $=\&$ docid $=83710 \&$ page Index $=0 \&$ doclang $=$ sk $\&$ mode $=1$ st $\&$ dir $=\&$ occ $=$ first $\&$ part $=1 \&$ cid $=1860605$.

18. Judgment of the Court (Grand Chamber) of 19 May 2009. Apothekerkammer des Saarlandes and Others (C-171/07) and Helga Neumann-Seiwert (C-172/07) v Saarland and Ministerium für Justiz, Gesundheit und Soziales. References for a preliminary ruling: Verwaltungsgericht des Saarlandes - Germany. Freedom of establishment - Article 43 EC - Public health Pharmacies - Provisions restricting the right to operate a pharmacy to pharmacists alone - Justification Reliability and quality of the provision of medicinal products to the public - Professional independence of pharmacists. Joined cases C-171/07 and C-172/07, http://curia.europa.eu/juris/document/document.jsf? 
FARMACIA, 2021, Vol. 69, 4

text $=\&$ docid $=78515 \&$ pageIndex $=0 \&$ doclang $=$ sk $\&$ mode $=1$ st $\&$ dir $=\& o c c=$ first $\&$ part $=1 \&$ cid $=1860605$.

19. Judgment of the Court (Grand Chamber) of 19 May 2009. Commission of the European Communities v Italian Republic. Failure of a Member State to fulfil obligations - Freedom of establishment - Free movement of capital - Articles 43 EC and 56 EC Public health - Pharmacies - Provisions restricting the right to operate a pharmacy to pharmacists alone Justification - Reliability and quality of the provision of medicinal products to the public - Professional independence of pharmacists - Undertakings engaged in the distribution of pharmaceutical products Municipal pharmacies. Case C-531/06, http://curia. europa.eu/juris/document/document.jsf?text=\&doci $\mathrm{d}=78517$ \&pageInde $=0 \&$ doclang $=$ sk\&mode $=1$ st \&d ir $=\&$ occ $=$ first $\&$ part $=1 \& c i d=1860605$.

20. Kališ R, A doctor from the mountains and neighbour pharmacist: specifics of rural health care. Monitor hospodárskej politiky, 2019; 4: 11-13, https://apps.who. int/iris/bitstream/handle/10665/326394/978928905 4249-eng.pdf?sequence=1\&isAllowed=y., (available in Slovak).

21. Lábaj M, Competition in regulated markets: functioning of pharmacies on Slovakia. Monitor hospodárskej politiky, 2019; 4: 7-10, (available in Slovak).

22. Malovecká I, Minarovič I, Mináriková D, Lehocká L, Snopková M, Foltán V, Globalization and its impact on pharmacy services in the Slovak Republic. Čes slov Farm., 2014; 63(1): 40-47, (available in Slovak).

23. Malovecká I, Minarovič I, Mináriková D, Snopková M, Lehocká L, Foltán V, Medical and entrepreneurial character of the community pharmacy. Čes slov Farm., 2014; 63(2): 84-89, (available in Slovak).

24. Mandžák P, Hronček P, Business in the pharmaceutical business. Monitor hospodárskej politiky, 2019; 4: 1418, (available in Slovak).

25. Mihanovic A, The impact of deregulation and liberalization in the pharmaceutical market in Croatia and potential strategic directions of development. Interdisciplinary Management Research, 2019; 15: 998-1012.

26. Padeiro M, Geographical accessibility to community pharmacies by the elderly in metropolitan Lisbon. Res Social Adm Pharm., 2018; 14(7): 653-662.
27. Růčková P, Financial analysis. GRADA Publishing, Praha, 2019, (available in Czech).

28. Smatana M, Pazitny P, Kandilaki D, Laktisova M, Sedlakova D, Paluskova M, van Ginneken E, Spranger A, Slovakia Health system review. Health Syst Transit., 2016; 18(6): 1-210.

29. Statistical Office of the Slovak Republic: DATAcube, http://datacube.statistics.sk., (available in Slovak).

30. Szalayová A, Skybová K, Kandilaki D, Szalay T, Analysis of the pharmacy market in Slovakia and the Czech Republic. Developments over the last 10 years. Health Policy Institute, Bratislava, 2014; www.hpi.sk/ cdata/Publications/hpi_analyza_lekarenskeho_trhu. pdf., (available in Slovak).

31. Štrangfeldová J, Ex-ante financial-economic analysis in pharmacy. Poradca lekárnika, 2012; 13: 13-16, (available in Slovak).

32. The Government of Hungary: Report No. B/1764 on the community pharmacies. Presented by $\mathrm{Z}$. Balog. Budapest, 2014; www.parlament.hu/irom40/ 01764/01764.pdf., (available in Hungarian).

33. The Government of Republic of Hungary: Report No. $\mathrm{J} / 1323$ on the practical application, expected and real impact of rules included in the act No. XCVIII. issued in 2006, concerning the community pharmacies, safe and effective supply of medicines and medical devices and general regulation of medicines trade. Presented by: M. Réthelyi. Budapest, 2010; www.parlament.hu/ irom39/01323/01323.pdf., (available in Hungarian).

34. Vogler S, Arts D, Sandberg K, Impact of pharmacy deregulation and regulation in European countries, Gesundheit Österreich GmbH, Vienna, 2012; https://docplayer.net/49613694-Impact-of-pharmacyderegulation-and-regulation-in-european-countries.html.

35. Vogler S, Habimana K, Arts D, Does deregulation in community pharmacy impact accessibility of medicines, quality of pharmacy services and costs? Evidence from nine European countries. Health Policy, 2014; 117(3): 311-327.

36. Volkerink B, de Bas P, van Gorp N, Study of regulatory restrictions in the field of pharmacies. ECORYS Nederland BV, Rotterdam, 2007; www.actasanitaria.com/ fileset/doc_42824_FICHERO_NOTICIA_19865.pdf. 